International Background Paper

Wealth Tax Commission

\title{
Wealth tax: Norway
}

Author Bettina Banoun OF ECONOMICS AND POLITICAL SCIENCE

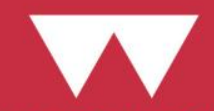
WARWICK Werex 


\section{WEALTHTAX: NORWAY}

Bettina Banoun, Wiersholm, Norway

Wealth Tax Commission Background Paper no. 138

Published by the Wealth Tax Commission

www.ukwealth.tax 


\section{Acknowledgements}

The Wealth Tax Commission acknowledges funding from the Economic and Social Research Council (ESRC) through the CAGE at Warwick (ES/L011719/1) and a COVID-19 Rapid Response Grant (ES/V012657/1), and a grant from Atlantic Fellows for Social and Economic Equity's COVID-19 Rapid Response Fund. 


\section{Brief history of wealth tax and its tax rate in Norway}

Norway has had wealth tax (formuesskatt) for more than a century. The wealth tax rate is currently (in 2020) $0.85 \%$ (0.15\% to the state plus $0.7 \%$ to the municipality). If the Labour Party wins the next election, the tax rate may be increased to around $1.1 \%$ (and $1.3 \%$ for wealth above NOK 20 million (EUR 2 million)).

Municipalities are allowed to implement a wealth tax rate lower than $0.7 \%$. There is, however, only one municipality in Norway, Bø in Vesterålen, that has reduced its wealth tax rate to a lower level. This municipality has a wealth tax rate of $0.2 \%$, which means that the total wealth tax rate for residents in this municipality is $0.35 \%$.

Net taxable wealth below a threshold of NOK 1.5 million (EUR 150,000) per person is not subject to net wealth tax.

In 2019, wealth tax amounted to approximately $1.1 \%$ of the total tax proceeds in Norway; NOK 16.1 billion (approx. EURO 1.6 billion) of NOK 1437.4 billion in total tax proceeds. ${ }^{1}$

The figure below ${ }^{2}$ shows the wealth tax revenue in NOK millions between 2006 and 2018:

08564: Survey of tax assessment for all persons, by survey of tax assessment and year. NOK million for all people.

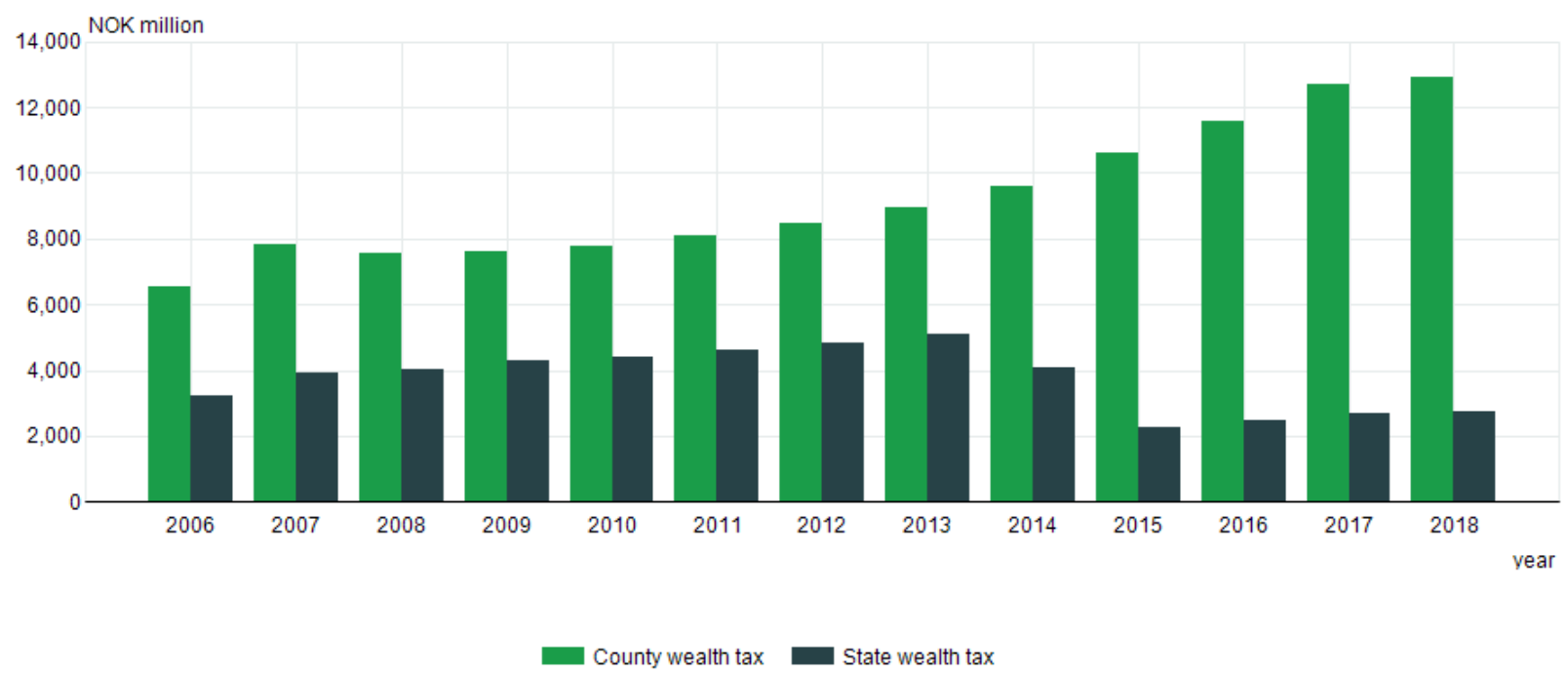

Source: Statistics Norway

The conservative parties have ruled in Norway since 2014. Even though the wealth tax rate has been reduced in this period from $1.1 \%$ to $0.85 \%$, and the valuation discounts on working capital have increased from $0 \%$ to $35 \%$ (45\% in 2021), the wealth tax yield has actually increased due to other changes in the valuation method for several assets (for instance commercial property).

\footnotetext{
${ }^{1}$ National budget 2020 p. 37 (16.1/1437.4). see https://www.statsbudsjettet.no/upload/Statsbudsjett 2020/dokumenter/pdf/skatt.pdf.

${ }^{2}$ https://www.ssb.no/en/statbank/table/08564/chartViewColumn/.
} 


\section{What assets are taxed?}

Individual taxpayers in Norway are liable to wealth tax on all assets according to section 4-1 of the Norwegian Tax Act: ${ }^{3}$

The taxable property is fixed at the market value, as at 1 January in the assessment year, of the taxpayer's assets that have a financial value less debt for which the taxpayer is liable.

In general, the wealth tax encompasses all assets that are owned by the taxpayer at the end of the year (31 December), irrespective of the type of assets and their location (global wealth tax principle).

Normally ownership is a requisite for wealth tax. However, income from and use of another person's assets or properties are taxed according to Norwegian Tax Act section 4-50:

If it has been prescribed, under a last will and testament or other valid legal arrangement, that the income generated by an asset or the use of a property shall, for a period of time, be reserved for one person, whilst the actual asset or property shall be accrued to another person, foundation or undertaking, the value of such asset or property shall be taxed on the part of the person holding the right to income from such asset or the right to use such property, for the duration of said right.

The Supreme Court has emphasised that the provision only applies if the right of actual use of the capital is held by the party that enjoys the income in a certain period of time, (cf. the Norwegian Supreme Court Reports; Rt. 1948 p. 1032):

Section 34, first paragraph, [now section 4-50], however, of the Norwegian Tax Act only concerns the fact that a person is not only entitled to a periodic benefit, but that he "enjoys the income from capital or the use of property" for a certain period of time. Thus, the right of actual use of the capital or the property is held by the person who enjoys the income. This will be the case when [...] the deceased has established that the interest on a certain amount must go to (a) for a certain period of time, after which the capital falls on (b).

(See further information below on trusts and foundations and recent case law.)

Several assets are exempted from wealth taxation, including conditional rights, time-limited rights of use, time-limited rights to periodical benefits, goodwill, know-how and salary claims, interest or dividends on shares, securities fund units and other securities, provided that such claims have not fallen due for payment, see section 4-2 of the Norwegian Tax Act:

(1) The following assets shall be excluded upon the calculation of taxable wealth:

a. conditional rights;

b. time-limited rights of use;

c. time-limited rights to periodical benefits;

\footnotetext{
${ }^{3}$ Unofficial translation of the Norwegian Tax Act made by PWC for Rettsdata.no
} 
d. claims for wages, interest or dividends on shares, securities fund units and other securities, provided that such claims have not fallen due for payment;

e. rights to creative works or patents, provided that such rights are still held by the creator or inventor;

f. goodwill;

g. technical, mercantile or other knowhow;

h. crops that are necessary for the farm operations;

i. equity capital, as well as premium reserves and equalisation reserves in savings banks;

j. life insurance policies established in order to meet mandatory contribution requirements in pension funds or widow's funds;

k. claims for gains as mentioned in Section 5-50, Sub-section 2 [certain gambling money], that have not fallen due for payment.

Thus, in practice, far from all assets are subject to wealth tax. The above-mentioned basic rule and exceptions thus make the total wealth tax level different for different types of investments. For example, a service provider with large investments in goodwill and know-how will generally be subject to a lower level of wealth tax than a capital-intensive business, which, for the most part, has investments in valuable tangible assets. Wealth tax for listed shares are generally substantially higher than for non-listed shares. 


\section{Defining the taxable person and territorial issues}

\subsection{Individual taxpayers and territoriality}

All individual taxpayers that are tax resident in Norway at the end of the year are liable to wealth tax to Norway. However, exceptions do apply for foreign students and diplomats.

Tax is levied per adult. The wealth of spouses are combined and parents' wealth includes the wealth of children under the age of 17 years.

Non-resident persons do not generally pay Norwegian wealth tax. However there are exceptions, for instance foreigners have to pay wealth tax for real estate in Norway.

\subsection{Judicial persons}

Limited liability companies (aksjeselskap), and other similar company types, are exempt from wealth tax. Instead, a company's personal shareholders are subject to wealth tax in respect of the value of their share of the limited liability company, provided that they are tax resident in Norway.

Also, state corporations, inter-municipal companies and securities funds are exempt from wealth tax.

Since partnerships under Norwegian tax law are tax transparent and thus are not classified as tax subjects, wealth tax on assets owned by partnerships are instead levied on the participants in the partnerships.

\subsection{Family foundations and asset funds}

Norwegian family foundations or asset funds are liable to pay wealth tax if the return on the capital primarily accrues to members of a specific family, see the Norwegian Tax Act section 232 (5):

(5) A family foundation and other asset funds in which the return on the capital primarily accrues to the members of a specific family shall be liable to pay wealth tax.

According to section 2-2 of the tax decision of the Norwegian Parliament (2020), the tax rate is $0.15 \%$ :

Enterprises and undertakings that are mentioned in section 2-36 second paragraph of the Norwegian Tax Act and that are not exempt from the liability to pay wealth tax pursuant to Chapter 2 of the Norwegian Tax Act shall pay wealth tax to the State at a rate of 0.15 per cent. Assets below NOK 10,000 shall be free of tax.

Such undertakings are exempt from tax to municipalities and county municipalities, see section 2-36 (2). Thus, Norwegian family foundations are liable to wealth tax only at a rate of $0.15 \%$ and the beneficiaries will only be exposed to wealth tax once a distribution to the beneficiaries has taken place. 


\subsection{Trusts}

As mentioned above, the Norwegian Tax Act section 4-50 includes a wealth tax provision for persons with rights to income from and use of assets or properties. This provision may for instance apply to a beneficiary of a fixed-income trust where the beneficiaries annually receive all income from the trust.

If the beneficiaries have full control over the trust, and can take back the trust's assets, the trust is sometimes disregarded for tax purposes.

In the Ptarmigan Trust case (see EFTA Court case no. E-20/13) the assets in the trust had, for tax purposes, been allocated by the tax authorities to the individual beneficiary in accordance with a mathematical fraction, based on the number of beneficiaries in the trust. ${ }^{4}$ The beneficiaries argued that they should not be regarded as the owners of the assets in the Ptarmigan Trust since it was a discretionary, irrevocable trust.

Both the district court and the appellate court found that the beneficiaries could not be regarded as owners of the trust's capital according to section 4-1 of the Tax Act. However, the appellate court expressed doubt:

The Court of Appeal has found the assessment difficult and has been in doubt about the outcome. After an overall assessment, the Court of Appeal has nevertheless found that the beneficiaries' lack of ownership rights, the conditional nature of the economic interest and the fact that the interpretation of "assets" in the Tax Code section 4-1 [wealth tax] does not rest on the same foundation as the expression "owner" in the Tax Act section 1062 first paragraph [CFC-tax], should be given decisive weight.

As mentioned above, the Norwegian Tax Act section 4-50 includes a wealth tax provision regarding taxation for persons with rights to income from and use of assets or properties. In the Ptarmigancase, the district court and the appellate court found that the provision did not apply to a truly discretionary trust, in which the beneficiaries are not entitled to the income of the undertaking. Here the appellate court also expressed some doubts:

The Court of Appeal, however, has been in doubt about the assessment since there are no other than the beneficiaries who receive benefits from the trust, with the exception of any charitable purposes. It can be argued that such a position must be sufficient to apply section 4-50. However, the Court of Appeal has found that the conditional benefits that the beneficiaries can receive is not such an "use of income" that is subject to wealth tax according to the provision. The government's objections that the beneficiaries "fall between two chairs", i.e. wealth taxes neither pursuant to section 4-1 or \$ 4-50, cannot be decisive.

The appellate court also considered Article 31/40 of the EEA Agreement and stated that Ptarmigan trust most likely is comparable to a Norwegian family foundation or asset fund. The high wealth tax on the beneficiaries of a trust is then problematic from an EEA point of view since beneficiaries to a Norwegian family foundation do not pay wealth taxes and the family foundation pay a considerably lower tax.

In the Ptarmigan Trustcase the state argued as a new submission that beinga beneficiary had a financial value, which is taxable pursuant to section 4-1 of the Tax Act.

\footnotetext{
${ }^{4}$ I represented the taxpayers in the case.
} 
The appellate court emphasised the fact that this question had not been dealt with by the tax authorities in the assessment decisions. Further, it was stated that taxation of such a 'limited right' / conditional right raises problems when it comes to valuation and would probably not be subject to wealth tax since the rights to benefits in a discretionary trust are subject to a condition:

During the appeal, the state stated a new subsidiary basis for wealth tax. The state claims that the position as beneficiaries constitutes a limited right which is an "asset" with economic value pursuant to section 4-1 of the Tax Code. The appeal counter parties claim that this is taxation of another "object" which falls outside the assessment decisions that are on trial. They further argue that this new foundation must be disregarded on a procedural basis. The state claims on its side that it is merely a different use of law on the same factual basis that is the basis for the application of the Tax Act \$ 4-50. [...]

The Court of Appeal finds reason to emphasize that the appeal counterparties under the administrative tax treatment stated that - if anything - the position as beneficiary should be subject to taxation. In the administrative decisions, this was explicitly rejected with reference to the fact that this was not the topic, cf. the Central Tax Office's decision of 24 August 2015, page 50. According to the Court of Appeal's assessment, it is difficult to find that this then is within the administrative decisions when this is argued in the appeal proceedings. In addition, this subsidiary basis raises other questions relating to conditional rights, cf. the Tax Act section 4-2 first paragraph letter a, and valuation. According to the Court of Appeal's assessment, it is hard to imagine how the limited right, which almost exclusively relates to the possibility of distributions and a share of the assets upon termination, may fall outside the scope of section 4-2, first paragraph, letter a. A valuation of such a limited right, even if it should be possible to transfer, will also be very challenging. None of these issues are touched upon in the decisions. For the Court of Appeal it is not necessary to take a final position on these questions, but they substantiate that the new subsidiary basis falls outside the decisions that are being tested.

The State appealed the wealth tax verdict to the Supreme Court, but the appeal was dismissed. 


\section{Valuation issues and liquidity concerns}

\subsection{General}

Under section 4-1 of the Norwegian Tax Act, the taxable value of an asset is equal to the market value of the asset. There are exceptions to this rule for certain assets, such as real estate and shares in unlisted companies. In the following, we will briefly discuss some of the main exceptions.

The specific 'valuation discounts' (verdsettelsesrabatt) have been subject to a comprehensive political discussion and have been amended several times.

The reason for giving specific valuation discounts on the valuation of shares, fixed assets and of real estate used for business purposes is to reduce the taxation of so-called 'working capital'. If the Labour Party wins the next election, the valuation discounts may be reduced.

As a temporary COVID-19 measure, taxpayers with a loss in 2020 may request for one year delayed payment of the wealth tax for 2020.

\subsection{Listed shares}

Shares in listed companies are valued at 65\% (55\% in 2021) of their listed price as of 1 January of the relevant tax assessment year (the year after the income year). The valuation discount applies for the valuation of shares both in companies resident in Norway and in other countries.

\subsection{Unlisted shares in Norwegian companies}

The valuation of shares in unlisted companies grants the same valuation discount as for shares in listed companies (reduction of $35 \%$ of the base value, proposed increase to $45 \%$ in 2021), but the valuation nevertheless differs in certain important respects.

First, unlisted shares in Norwegian companies are valued at $65 \%$ (55\% in 2021) of the proportion of the company's total tax value as of 1 January of the income year. A proportion of the company's total value is attributable to each share, on the basis of the nominal value of such share.

If the company owns assets that have a lower tax value compared to its market value (e.g. real estate), this will be reflected in the valuation of the shares. Goodwill in an unlisted company is not taken into account in the valuation of the shares. As a result, the most significant values in some companies, for example an IT company, are not reflected in the value of the shares when wealth tax is calculated.

The reason for this choice of valuation method is that the market value of shares in unlisted companies often is not known, as opposed to shares in listed companies, and it would thus be difficult in practical terms if the wealth tax value of the unlisted shares was to be determined based on the shares' market value.

Second, the valuation is to be based on the tax value of the company's assets as of 1 January of income year, as opposed to 1 January in the assessment year, which, as mentioned above, is the main rule when valuing assets for wealth tax purposes. The tax value of the company's assets is calculated and declared in the company's tax returns, which are filed in the spring in the year after the relevant income year (e.g. the tax return for 2020 is filed in the spring of 2021). The 
information needed to calculate the shareholder's wealth tax base may not be readily available at the time when the tax return is submitted. Therefore, the point in time for valuing unlisted shares in Norwegian companies is brought one year back compared to other assets.

\subsection{Unlisted shares in foreign companies}

Unlisted shares in foreign companies are valued at $65 \%$ (55\% in 2021) of the presumed sales value of each share as of 1 January in the tax assessment year.

However, the taxpayer may request that the shares are instead valued by using the same valuation method as for unlisted shares in Norwegian companies, provided that the taxpayer is able to document the tax value of the foreign company's assets.

\subsection{Primary residences, holiday homes and commercial property}

Residential properties are normally valued based on calculated square metre prices, which are based on price statistics for residential properties sold in the area. Commercial property is normally calculated on the basis of an estimated letting value. There is a 75\% discount for primary residences and holiday homes, and 10\% for secondary residences. For 2021 it is proposed that the $75 \%$ discount on primary residences only shall be granted for residences with a value up to NOK 15 million (EUR 150,000). Above this level there will be a $50 \%$ discount, instead of the $75 \%$ discount. There is a $35 \%$ ( $45 \%$ in 2021 ) discount for commercial property. The value of primary residences and holiday homes is to be reduced at the request of the taxpayer if it exceeds $30 \%$ ( $25 \%$ in 2021 ) of the documented sales value of the property. The valuation rules for properties are set out in the Norwegian Tax Act section 4-10 (as per 2020):

(1) The value of real estate may be put below its sales value. The value of primary residences and holiday homes shall be reduced at the request of the taxpayer if it exceeds 30 percent of the documented sales value of the property. The value of commercial property shall be reduced at the request of the taxpayer if it exceeds 78 percent of the documented sales value of the property. The value of other residential properties (secondary residences) shall be reduced at the request of the taxpayer if it exceeds the documented sales value of the property.

(2) The value of residential property shall be calculated by multiplying the square metre area of the residence by a square metre rate. The square metre rate shall be a percentage of estimated sales value per square metre rate, taking into consideration the type of residence, year of construction, size and geographical location. The percentage shall be 25 for primary residences and 90 for secondary residences. The square metre rates shall be determined annually by the Directorate of Taxes on the basis of calculations from Statistics Norway.

(4) The value of commercial property may be calculated on the basis of an estimated letting value. Valuation pursuant to the first sentence may apply differentiated square metre rates. The value of commercial property shall be put at 65 percent of the estimated letting value of the property.

The youth organisation of the Labour Party has recently expressed that they will aim to reduce the valuation discount for primary residences from $75 \%$ to $20 \%$ and remove the valuation discount for holiday homes. If the Labour Party wins the next election (in September 2021), the valuation discounts thus may be reduced. 


\subsection{Deduction for liabilities}

Liabilities associated with assets eligible for the valuation discounts on working capital are reduced correspondingly, to avoid a reduction of wealth tax through the gearing of assets eligible for valuation discounts. 


\section{Relationship with other taxes}

For many years, Norway had both wealth tax, gift tax, inheritance tax and property tax at the same time, in addition to income tax and tax on capital gain. The inheritance tax/gift tax was abolished in 2014 by the conservative parties. It might, however, be reintroduced in 2021 . The use of property tax has increased in the recent years.

Wealth tax is not deductible or creditable against any other tax. No relief is given in wealth tax in respect of charitable donations.

The valuation method used for residence homes are used both for wealth tax and property tax (with different valuation discounts). The valuation method for wealth tax on family homes is considerably more favourable than the valuation method used for estate tax on family homes. 


\section{Planning and enforcement}

Norway has a self-assessment regime both for wealth tax and for tax on income and capital gain. In addition information about the individual wealth base is sent to the tax authorities from banks, listed and unlisted companies etc (third party information). Wealth tax is assessed annually. Advance payment is paid four times annually based on a prefixed tax return that includes the wealth base.

A problem with the Norwegian wealth tax is that there is no cap on the wealth tax. Especially for the extremely wealthy the most effective way to avoid Norwegian wealth tax is either to move from Norway or to give the assets away, for instance to a charitable foundation. In Norway, there are strict emigration rules. To avoid being tax resident in Norway the person has to, for three consecutive years, fulfil the following requirements: (i) they cannot have a dwelling in Norway available to them, and (ii) they cannot spend more than 61 days each year in Norway. A person that moves from Norway in year 1, needs to fulfil these requirements in year 2-4, and will avoid wealth tax from year 5 . Some tax treaties will give relief earlier, for instance already in year 1 if the person is deemed tax resident in Switzerland and liable to wealth tax in Switzerland.

If the taxpayer wishes to stay in Norway and keep his/her fortune, the second most effective way is to reduce his/her wealth tax by investing in assets with valuation discounts, for instance in a primary residence, holiday homes or shares in unlisted companies, and to avoid public listing of companies.

Even though wealth tax is substantially lower for family foundations, there do not appear to be many Norwegian family foundations or asset funds. The use of foreign trusts are not widespread.

There is a general anti-abuse rule (GAAR) in Norwegian Tax Act section13-2 that might apply also for wealth tax. There are not many examples of use of the GAAR for wealth tax purposes. There are no targeted anti-abuse rules regarding wealth tax. In 2019 some loopholes have been closed through targeted legislation. 